\title{
PROTEST SOCIO-POLITICAL MOVEMENTS AND ORGANIZATIONS AND THEIR TRANSFORMATION IN THE LATE 1980S. IN THE MODERN COUNTRIES OF THE VISEGRAD GROUP
}

\section{Koltsov V. M.}

\section{INTRODUCTION}

The consequence of the introduction of the concept of democratization and modernization of socialism incorporated in the processes of «perestroika» as an alternative to the political regime which, being «obsolete», took place in the second half of the 1960s, as well as the systemic crisis in the socio-economic and socio-political spheres was that from the late 70's, but more from the middle - the second half of the 80's of the twentieth century in Poland, Hungary and Czechoslovakia the structural and organizational network of protest began to expand, which as a result turned out to be a variation of the transition from dissidence to opposition (in the «resistance - dissidence - opposition» triad).

However, such a transition from dissidence to opposition was not straightforward and one-vector, but was mainly carried out in the categories of protest socio-political movements and organizations, which eventually substantially and conceptually transformed into political opposition, in particular through the prism of its understanding as a form of social / sociopolitical protest.

In this context, the ideas of J. Rothschild, M. Sczabo, and G. Schopflin that the modern countries of the Visegrad Group, until at least the 1980s, were not characterized by widespread practice of protest socio-political movements - that is, processes of civil society - deserve attention, mobilized for the support of specific socio-political demands and non-institutionalized or partially institutionalized collective actions that sought to mobilize broad public support in order to achieve the publicly-formed goals and requirements of workers. That is, as Jenkins points out, no social movements were created in the region until a certain period of time, which were collective actions, envisaged deliberate actions to change individual and social institutions and non-institutional forms of political participation that would be characterized by such attributes (as ideology) conceptual structure 
based on an awareness of the importance of collective action, organization (a way of coordinating collective action and the environment (the participation of various actors in the design of socio-political actions that target the protest groups ${ }^{1}$.

It was only in the aftermath of the events of the partial liberalization of the communist regime in the 1960s, as well as during and on the basis of the socio-political and socio-economic crisis of the early and mid-1980s that made leadership structures immobile and subordinate conservative bureaucratic interests (less so in Czechoslovakia, where the communist regime held on to a comparatively more coercive state-party apparatus and more pronounced support for the Soviet Union), in the midst of dissent and other social groups (and communist parties) matured at least some chance of protest against the regime of «real socialism» ${ }^{2}$. Although these opportunities were never institutionalized, they were accordingly dependent on the «goodwill» of the Soviet and national political regimes, as well as on the regional patterns of new mobilization perspectives embodied in the form of a protest culture aimed at democratization. Thus, the emergence of political opportunities in Poland, Czechoslovakia and Hungary for the mass mobilization and development of protest culture was driven primarily by the general trend of the decline of the communist regime in the region and the response of the national socio-political environment.

\section{Formation and functioning of protest socio-political movements in the modern countries of the Visegrad Group}

The formation, functioning and consequences of protest socio-political movements in the modern countries of the Visegrad Group were quite different, and therefore they require both a consistent separate review and a consolidated comparative analysis. It must begin with the observation that the phenomenon of socio-political movements is quite different from the phenomenon of dissidence (even including it) ${ }^{3}$. And not only in the achieved results, but also structurally and systematically. Thus, dissidence emerged as a reaction to the collapse of the «revisionist project» of the creation of «socialism with a human face» and to the «strict» conservatism of the Brezhnev era. Accordingly, dissidence was positioned primarily as a form of

\footnotetext{
1 Jenkins R. Movements Into Parties: The Historical Transformation of the Hungarian Opposition. Program on Central and Eastern Europe Working Paper Series. 1992. No. 25. $80 \mathrm{p}$.

${ }^{2}$ Batt J. The End of Communist Rule in East-Central Europe. Government and Opposition. 1991. Vol. 26. No. 3. P. 368-390.

${ }^{3}$ Bernhard M. Civil Society and Democratic Transition in East Central Europe. Political Science Quarterly. 1993. Vol. 108. No. 2. P. 307-326.
} 
moral conviction addressed to challenge the position of the «party-state» and its activities ${ }^{4}$. In turn, and in view of the collapse of the concept of revisionist Marxism and the «overflow» of dissidence into the sphere of human and citizen protection, protest socio-political movements were more constructed on the logic and strategies of opposition resistance. It turned out that, relying primarily on the «forces» of society, for the first time in the conditions of «real socialism» regimes, they began to put pressure on political power and the party-state over how they functioned and were supposed to function. Moreover, the protest socio-political movements resorted to rhetoric about the need to reform the existing systems of regimes of «real socialism», in particular the instruments of influence of the contradictions of social resistance and opposition, which first felt and exploited the existing contradictions. This, according to L. Kolakovsky, meant that political protest groups concealed themselves as instruments and mechanisms of opposition, as they resorted to a «reformist orientation in the sense of believing in the possibility of effective, gradual and partial pressure», in particular with a view to a «long-term perspective» social and national liberation ${ }^{5}$ and towards a long-term strategy for the behavior of socio-political movements ${ }^{6}$. Accordingly, the appearance of sometimes in the late 70's, but mostly in the middle - the second half of the 80's of the twentieth century of protest groups with outlined ideological and programmatic postulates meant the transformation of the very phenomenon of protest from a format of dissidence into a format of political opposition incorporated in the form of socio-political movements ${ }^{7}$.

For the first time protest / opposition socio-political movements began to take shape in Poland in the late 1970s, marking the emergence of the first opposition (as a form of social / political protest) in the Soviet bloc. For example, in 1976, the first step in self-liberalization of civil society in Poland emerged, as a result of the failure of the workers' strike resulted in the first attempt under the communist regime to implement the opposition rather than the dissident line of resistance. The most important social actor in creating such a protest was the Workers Protection Committee (KOR). In addition, other protest groups with highly diversified political or ideological orientations competed with the Committee. So, over time, the largest «public space» in the region for protest / opposition activity was generated in

${ }^{4}$ Rakovski M. Towards an East European Marxism. New York: St. Martin's, 1978. P. 105.

${ }^{5}$ Kolakowski L. Hope and Hopelessness. Survey. 1971. Vol. 17. P. 48.

${ }^{6}$ Michnik A. The New Evolutionism. Survey. 1976. Vol. 22. P. 274.

7 Кольцов В. Вплив протестних суспільно-політичних рухів і організацій на формування політичної опозиції в сучасних країнах Вишеградської групи (70-80 роки ХХ століття). Молодий вчений: науковий журнал. 2017. № 6 (46). С. 28-32. 
Poland, which in fact initiated the process of limiting the dependence of public interests on the state. In this space, the leading protest / opposition movement was the Solidarity movement, which even though it was weakened in the early 1980s, in particular by the pressure of the communist regime, soon revealed that the party-state was simply not able to reform successfully the «stagnant» Polish economy, and therefore completely isolate the protest / opposition, first and foremost in the expression of Solidarity, from its sources of social support. Moreover, it was the organizational and political experience of members of the protest / opposition Solidarity that had a tremendous impact on the further deployment of the political process in Poland. The culmination was the «contract» between the authorities and the socio-political movements, which eventually peacefully during the February-April 1989 roundtable negotiations and the partially free parliamentary elections in June 1989 led to the collapse of the «real socialism» regime and the democratization of Poland.

The result of these processes is that: - independent trade unions are legalized; the election of the president-elect was first introduced by parliament, and subsequently nationwide (with the cancellation of the General Secretariat of the Polish United Workers' Party); a bicameral parliament within the Seimas and the Senate was formed; incorporated the practice of the «Contracted Seimas» (a communist V. Jaruzelsky was elected the president, a prime minister - a representative of «Solidarity» T. Mazowiecki, and there was an agreement on the distribution of the maximum number of mandates for «Solidarity» with the predominance of the opposition regime of social and political movement.

In the course of the processes exemplified in Poland, as well as on the basis of their experience, the formation of protest / opposition movements and anticommunist transformations in other countries of the modern Visegrad Group and in the USSR as a whole began (often this is the basis of the question of the primacy of not the «Gorbachev effect» but «The effect of Poland»), which led to the collapse of the communist regime in the region ${ }^{8}$.

Thus, the case of Poland demonstrated and signaled that processes were possible: peaceful/concerted delegitimization and change of political regime; maneuvering and legalization of political protest groups; ensuring freedom of the press, speech, conscience and association; political participation and

${ }^{8}$ Kenney P. A Carnival of Revolution: Central Europe 1989. New Jersey: Princeton University Press, 2002. P. 2. 
electoral competition ${ }^{9}$. In turn, Poland's «exclusivity / uniqueness» was due to the fact that: a) protests and opposition in this country were constructed on the basis of the experience of earlier "waves» of the working and intellectual opposition to the communist regime ${ }^{10}$; b) Communism in this country has never been interpreted as a «natural» phenomenon, but rather as a phenomenon implanted by Poland's «historical enemy» - backward Russia - making the legitimacy of the communist regime positioned as a threat to Polish national sovereignty ${ }^{11}$; c) the communist regime did not outline the current and urgent sociopolitical divisions existing in Poland after World War $\mathrm{II}^{12}$, and therefore Poland did not get used to positioning Russia artificially as a «friend» and Germany as an «enemy»" ${ }^{13}$, as a result, the protest groups recognized the right to the political subjectivity of all other Polish neighbors; d) the communist regime in Poland failed to deny the «moral status» and autonomy of the Catholic Church, so the election of Pope John Paul II only strengthened anti-communist antagonisms in Polish society and consolidated their working and intellectual resources and manifestations ${ }^{14}$.

The results of such a signaling of Poland's experience influenced primarily Hungary, where negotiations of protest/opposition socio-political movements and the communist regime began shortly after the «round table» in Poland. On the other hand, protest groups in Hungary were much weaker than in Poland, as they never felt strong enough to speak «on behalf of society» and negotiate «compromise democratization» with representatives of the «old regime». Accordingly, the Hungarian «oppositionists» have resorted to a strategy of uncompromising, that is, to demanding free elections as a mechanism for legalizing political protest. In this context, it is interesting that the first protest/opposition socio-political movements in Hungary, as well as in Poland, began to take shape in the late 1970s. - first

9 Bruszt L., Stark D. Remaking the Political Field in Hungary: From the Politics of Confrontation to the Politics of Competition. Banac I. Eastern Europe in Revolution. Ithaca: Cornell University Press, 1992. P. 13-71.

${ }^{10}$ Ackerman P., Duvall J. A Force More Powerful. A Century of Nonviolent Conflict. New York: St. Martin's Press, 2000. 544 p.

${ }^{11}$ Prizel I. National Identity and Foreign Policy. Nationalism and Leadership in Poland, Russia, and Ukraine. Cambridge University Press, 1998. P. 103.

12 Snyder T. The Polish-Lithuanian commonwealth since 1989: national narratives in relations among Poles, Lithuanians, Belarusians and Ukrainians. Nationalism and Ethnic Politics. 1998. Vol. 4. No. 3. P. 5.

${ }^{13}$ Curp T. The politics of ethnic cleansing: The P.P.R., P.Z.Z., Wielkopolska nationalist revolution, 1944-1946. Nationalities Papers. 2001. Vol. 29. No. 4. P. 588.

${ }^{14}$ Sonntag S. Poland. Pollack D., Wielgohs J. Dissent and opposition in communist Eastern Europe: origins of civil society and democratic transition. Ashgate, 2004. P. 18. 
of all, from dissident groups. However, quantitatively, structurally, organizationally, ideologically and typologically, the Hungarian protest or opposition was much smaller than the Polish one, and therefore was able to be systematized only in the second half of the 1980s. Moreover, the protest in Hungary was characterized by the fact that it concentrated mainly around large cities, above all Budapest, and for the most part, not the workers, but the intellectuals of the liberal and social democratic ideological orientation. However, the biggest difference between the Hungarian protest / opposition and the Polish one was that it was strongly supported or at least not denied by the reformist wing of the Communist Party. This played a crucial role in promoting civil society in Hungary in the late 1980s. ${ }^{15}$. The situation in this country began to resemble Poland when the phenomena of the socioeconomic crisis emerged, and in particular, in 1987, several rather influential networks of independent initiatives, independent trade unions and environmental movements were created at once ${ }^{16}$. The most influential were the populist-nationalist Hungarian Democratic Forum (MDF, 1987), the liberal Union of Free Democrats (SzDSz, 1988) and the nationalconservative Fidesz (1988). However, in general, the protest / opposition socio-political movements in Hungary (which were almost immediately transformed into parties) remained not very influential for some time. Instead, they were significantly stimulated by the reformist wing of the Hungarian Communists, which catalyzed the restoration of civil society in the country. On this basis, at the end of 1987, the communist regime began informal negotiations with official mass organizations created by protest / opposition groups as well as new reform groups ${ }^{17}$. As a consequence and in view of the political influence of Poland, the roundtable negotiations in June 1989 regulated the first fully free parliamentary elections in the spring of 1990. The victory was firmly won by a coalition of parties led by the Hungarian Democratic Forum, which was able to get more votes than other post-protest and post-communist parties - SzDSz, Fidesz, the Hungarian Socialist Party (MSZP) (reformed communists), etc. ${ }^{18}$.

As regards Czechoslovakia, protests / opposition socio-political movements were extremely weak and dispersed in this country (especially in

15 Gati C. Reforming Communist Systems: Lessons from the Hungarian Experience. Griffith W. Central and Eastern Europe, The Opening Curtain. Boulder, CO: Westview Press, 1989. P. 235-236.

${ }^{16}$ Urban L. Hungary in Transition: The Emergence of Opposition Parties. Telos. 1989. Vol. 79. P. 115.

${ }^{17}$ Hankiss E. In Search of a Paradigm. Daedalus. 1990. Vol. 119. No. 1. P. 205.

${ }^{18}$ Bozöki A. Post-Communist Transition: Political Tendencies in Hungary. East European Politics and Societies. 1990. Vol. 4. P. 228-229. 
the Czech and Slovak units). This was conditioned by years of repression by the communist regime in the aftermath of the Prague Spring in 1968. However, one of the attempts to form protest social and political movements took place in the late 1970s in the form of Charter 772 and the Committee on the Protection of the Unjustly Persecuted Persons ${ }^{19}$, but these expressions of protest were positioned on the brink of dissidence and opposition. On the other hand, the renewal of the influence of civil society was not caused by mass demonstrations under the auspices of protest groups, but by means of mobilization influence in the public groups. This happened in the late 1980s, when the atmosphere of fear and repression in Czechoslovakia began to decline as a result of a change in party leadership and the beginning of «perestroika» in the USSR, and as a result public demonstrations. It was as a result of the crackdown on one of these demonstrations involving students in Prague on November 17, 1989 that a «velvet revolution» against the communist regime began in Czechoslovakia ${ }^{20}$. As a result of such processes, organizations were formed in the Czech and Slovak part of the federal state (which did not have the status of socio-political movements, although formally / legally), such as the Civic Forum (OF) and the Society against Violence (VPN, respectively). Altogether, this determines that due to the relative weakness of the Czechoslovak opposition and limited «public space», democratic change was only possible if protest groups and organizations were able to direct spontaneous, unorganized and mass demonstrations by the far-flung parties from the far-flung party. Thus, civil society in Czechoslovakia was restored only after the "public space» had been «seized» by a spontaneous popular uprising, which allowed the opposition to be mobilized against the party-state. It is because of this logic of the event that the communist regime not only negotiated with protest groups and the public, but in fact escaped power.

It is worth noting that in these countries protest social and political movements and organizations, especially in the period from the second half of the 70's of the XX century and until 1987-1990, they acted as «agents» of anti-communism and anti-authoritarianism, because they fought first and foremost any manifestations and later remnants of the communist regime. Also, summarizing the peculiarities and tendencies of the formation and existence of socio-political movements in Poland, Hungary and Czechoslovakia, it is obvious that they were averagely characterized by

${ }^{19}$ Skilling G. Czechoslovakia Between East and West. Griffith W. Central and Eastern Europe, The Opening Curtain. Boulder, CO: Westview Press, 1989. P. 256.

${ }^{20}$ Wolchik S. Czechoslovakia's «Velvet Revolution». Current History. 1990. Vol. 89. No. 551. P. 413-416, 435-437. 
certain common and distinct attributes. The common attributes or patterns of protest socio-political movements in the region were the following tendencies: the attachment directly to illegal or semi-illegal protest groups of the communist political regime during its political and socio-economic crisis and the «perestroika»; postulation as a «debt» due to the influence of the anti-communist repressive-intolerant apparatus of the mobilization resistance and opposition to the political regime; appeals to issues of pre-communist nature - for example, national and ethnic sociopolitical divisions - that have persisted in the political culture of civil societies of the communist period; appeals to strategies for reforming «real socialism» regimes, in particular the construction of dogmatic and alternative socialism and social democracy, taking into account the traditions of the interwar period; articulation as «alternative» issues of peace and environmental protection ${ }^{21}$; positioning in the form of a «protest market» based mainly on trade unions and NGOs, concentrated more around urbanized rather than regulated areas; organization in the form of mobilization resistance to communist economic, social and cultural structures ${ }^{22}$, as well as based on historical and existing socio-political divisions and integrative norms and values (in the form of protest culture).

It is also noteworthy that the confrontation between the communist regimes and political protest groups in the region was quite similar, as the conflicting or rival parties/groups (communist power and anti-communist opposition) were interconnected in the fact that they could not solve the political crisis without help and assistance influence of each other - that is, they could not unilaterally impose the desired solution for each other if they really wanted to satisfy their different interests. Accordingly, in different countries at different times (for example, in Poland and Hungary predominantly until 1987, and in Czechoslovakia until 1989), including on the basis of fears of social and political upheaval, the need to construct a new one was clearly recognized social compromise «or» anti-crisis pact «by leading politicians and actors of the communist regime and anti-communist protest/opposition. Accordingly, it was the agreed form of peaceful interaction between the communist government and the anti-communist opposition that was the defining concept and strategy for the interaction of these forces. There were two explanations for this: first, the representatives of the protest groups believed that a revolution and any other form of violent political change could only lead to the emergence of another repressive

${ }^{21}$ Bugajski J., Pollack M. East European Fault Lines. Dissent, Opposition and Social Activism. Boulder, San Francisco, London: Westview Press, 1989. P. 200-217.

${ }^{22}$ Tilly C. From Mobilization to Revolution. Addison-Wesley, 1978. P. 35-40. 
political regime; second, they argued that violent political changes could not only jeopardize the possibility of a democratic order, but also undermine the chances of preserving human rights.

For the Communist parties, «pact» and «non-violence» were relevant in view of their desire to remain in power at least in part, because: on the one hand, their position on protest groups meant the official recognition of the right to form and operate groups that were always perceived by the regime's supporters as «enemies» and constantly suppressed; on the other hand, supporters of the «old regime» relinquished monopoly political power, guided by fear and «ghosts» of «white terror» by oppositionists. Overall, according to L. Bryusht, this means that the Communist parties were expecting the implementation of at least one of the two political strategies: a)»defense mobilization» in the form of controlling «top» political negotiations, preserving the role and status of communist parties, and «freezing» the balance of political forces with a tendency to block the emergence of other protest / opposition groups; b) separation of powers on the basis of a compromise between Communist parties and protest organizations, on the basis of which the former would be positioned as moderately authorized and moderately responsible parts of the coalition political process, alongside the latter. In turn, protest/opposition sociopolitical movements have «sacrificed» their moral and political authority and the concept of the so-called «new evolutionism». Moreover, protest movements were not decisively convinced that negotiations and compromise with the communist regime necessarily and utterly should have meant the collapse of the latter, and therefore they were in "constant fear» of radicalizing political protest / opposition in different countries of the region, and especially in Poland ${ }^{23}$.

It is also noteworthy that anti-communist socio-political movements were of varying influence - for example, weaker in Czechoslovakia, but stronger in Poland and Hungary - and lasting - for example, most tested in Poland, much less in Hungary, and least in Hungary in Czechoslovakia which is why they have led to different scenarios of the collapse of the communist regime and transit to democracy. At the same time, as D. Pollak and G. Eckert point out, the collapse of the «real socialism» regimes was influenced not only by the successes of protest anticommunist socio-political movements, but also by the "Gorbachev factor» and "perestroika» in the Soviet Union, by the fragmentation of Soviet power elites in the beginning. in the mid-1980s, the destructive impulse of the «surge in the Soviet empire»

${ }^{23}$ Siedlecki M. Time for Positive Action. East European Reporter. 1989. Vol. 3. No. 4. P. 35 . 
and more. Or, in other words, the collapse of communism in the region was systemically conditioned and accidental, because it was caused by both endogenous and exogenous factors, one of which was the increase in the influence and success of protest socio-political movements ${ }^{24}$.

It should also be noted that three key factors configured variations at first to change and subsequently to the collapse of «real socialism» regimes in contemporary Visegrad countries: the mobilization of the general population and civil society in particular; the ability of protest / opposition groups to act; the level of cohesion of the communist leadership and the quality of its response to the crisis of the system. These factors, in sum, generated two models of the impact of political protest on the collapse of «real socialism» regimes. According to the first model inherent in Czechoslovakia, the key factors of the communist crisis were not the role of protest/opposition groups, and the impact of the mobilization of the public and the inability to respond adequately to the individual (especially loyal) parts of the disintegrated consequences of the socio-economic crisis of the elite «old regime». Accordingly, socio-political movements / counter-attacks, which were also often not ready for diffuse and spontaneous manifestations of population mobilization, were able to act in response to the «vacuum» of political power, which was «warmed» by the sentiment of civil society (such a model of political protest influence averaged referred to as «implosion» or «replacement»). Instead, according to the second model, which was typical for Poland and Hungary, the main factors of the crisis of communism were the confrontation of some (especially reformist) facts of the Communist parties and political protest / opposition groups, which were «warmed up» by the influence of mobilization activities in the public / community environment. In view of this, the collapses of the «real socialism» regimes have taken place unplanned and unjustified, but as attempts to modify them partially, in particular to neutralize partially hardline supporters in the environment of communist parties and prevent the escalation of social and political conflicts.

\section{General characteristics of the consequences of protest socio-political movements in the Visegrad countries}

The consequences of the transformation of protest socio-political movements and organizations into political opposition (as a form of political

24 Ettrich F. Die «Zerstörung des Zerstörten» (Hegel). Der Zusammenbruch des Sozialismus sowjetischen Typs als sozialwissenschaftliches Problem. Brussig M., Ettrich F., Kollmorgen R. Konflikt und Konsens: Transformationsprozesse in Ostdeutschland. Leske, Budrich, Opladen, 2003. P. 231. 
protest) in Poland, Hungary and Czechoslovakia (Czech Republic and Slovakia) were the following: the practice of functioning as a determinant communist political system was discontinued and the systematic transformation of the state started; the process of democratization has begun in the form of involvement in the political process of legalized opposition configurations; the social expenditures system has been liberalized for different ways and variants of representation of social and political, including protest, interests; institutional mechanisms for guaranteeing public participation and representation in the socio-political process and public administration have been formed and tested ${ }^{25}$. As a result, in particular, on the basis of roundtables between representatives of the communist regime and protest socio-political movements in 1989, the region eventually began transformational processes, which were accompanied by the expansion of the sphere of protest, and consequently the expansion of the demands and goals of the socio-political movements. These changes, in turn, affected the further acceleration and variation of the dynamics of mass mobilization of political protest, as the collective actions of representatives of political protest / opposition groups began to be more frequent and drastic.

All this is incorporated in the fact that it is from the late 80's - early 90's of the XX century (and peaked in 1989-1993) and to this day civic activism in the modern countries of the Visegrad Group has started to be and still is an important element of political culture and a catalyst for institutional politics incorporated in the institutionalization of relations between the authorities and the opposition ${ }^{26}$. The manifestation of this was that, directly from the results of the impact of socio-political movements and the general public on the collapse of the communist regime, any existing conflicts between institutionalized political actors, in particular the government and parliamentary and non-parliamentary (generally political) opposition, can easily oppose the opposition and enhance the political role of protest. And in general, it is argued that the influence of protest socio-political movements and organizations on the formation of political opposition and the collapse of the regimes of «real socialism» in the modern countries of the Visegrad Group generated the perception of the phenomenon of socio-political protest as legal, institutionalized and non-political part of culture actions in the region $^{27}$. On this basis, M. Scabo argues that socio-political / political protest

${ }^{25}$ Szabo M. Some Lessons of Collective Protests in Central European Post-Communist Countries: Poland, Hungary, Slovakia, and East Germany Between 1989-1993. East Central Europe. 2000. Vol. 27. No. 1. P. 59-75.

${ }^{26}$ Ekiert G., Kubik K. Contentious politics in new democracies: East Germany, Hungary, Poland, and Slovakia, 1989-1993. World Politics. 1998. Vol. 50. No. 4. P. 554.

${ }^{27}$ Ibid, P. 554. 
in the form of opposition movements and organizations during and after the period 1987-1990 began to position itself as a central element in changing the political regime and consolidating the new political system in the Visegrad Group countries.

At the same time, an important role in defining the attributes of functioning of protest socio-political movements and organizations in the modern countries of the Visegrad Group, in particular through the prism of their opposition to the communist regimes, was to take into account how these movements and organizations developed further - mainly before and after the first democratic (constituent) parliamentary or presidential elections. In this section, it is clear that the first (constituent) elections played the role of a «springboard in the form of a referendum», in which protests and opposition communist movements and organizations demonstrated their formal anticommunist orientation and a far-sighted prospect of democratic reform and transformation. At the same time, given the Western political tradition and civilizational progress, to which the opinions of apologists of the processes of democratization by the forces of socio-political movements and organizations in all analyzed countries were «tied,» their further political discourse simply could not take place in structured or unstructured ones, but established organizational framework. It had to be defined and determined by more specific institutional procedural mechanisms. Accordingly, this specificity has been decisive in the transformation of protest socio-political movements and organizations in the party, which, as experience shows, have become the primary agents of transformation and, in particular, the institutionalization of political opposition, in the modern countries of the Visegrad Group not only in the way of their democratization, but and on the path of their integration into the EU.

The initial transformation of protest socio-political movements and organizations into political parties in the analyzed countries took place in 1989-1993, or in the period between the preparation for the first democratic (constituent) and the first multi-party (in the sense of political party participation) elections (namely in this period Czechoslovakia transformed into the Czech Republic and Slovakia, and soon the newly formed Visegrad Group began to be referred to as four countries).

Analytically and comparatively, such dynamics are crucial for several reasons. First of all, given that all of these countries have previously been or are currently being evaluated as consolidated or semi-consolidated democracies, so taking into account the experience of forming political parties in them is important for constructing / refining the theory of 
democratic transit ${ }^{28}$. Secondly, given the fact that the different dynamics of the processes of these protest socio-political movements and organizations have differently influenced their future positioning and delineation of the essence of political opposition within the different systems that emerged on the place of communist regimes.

For this reason, comparative analysis of the transformation of protest socio-political movements and organizations into political parties, as well as the failures of this process in individual countries, should be carried out in a constant and close mutual relation to such indicators as political activity at the level of movements, organizations and parties, organizational experience and attributes of the political (in the context of democratization and democracy) regime. Such correlation is needed to answer the question of why some protest movements and organizations, including the umbrella structures, led to the emergence of stable institutionalized systems with influential parties, while others led to the fragmentation and organizational weakness of political parties and party systems. In practical terms, this is as follows: why, for example, the powerful Polish «Solidarity» protest movement with deep rootedness in society could not form any stable or successful political party that would remain in power during the postcommunist period, or why Hungary's relatively weak divided, small and isolated opposition protest groups have been able to form parties that are centralized, resilient, and widely supported.

To address this range of issues in the context of political opposition, scientific evidence has been taken as a basis to show that the formation of parties and party systems in Poland, Slovakia, Hungary and the Czech Republic, especially in terms of their stability and institutionalization, are based on electoral features of the political process and attributes of existing socio-political divisions. They are, as M. Duverger points out, determined how party systems are fragmented, structured and stable. In addition, it is noted that all the socio-political divisions that existed in Poland, Hungary, the Czech Republic and Slovakia from the late 1980s to the mid-1990s were not as significant as expected theoretically. On the other hand, previous studies of the influence on the party systems of the countries of the region of the phenomena of the ideological concentration of electorates of different polities $^{29}$ played a significant role in evaluating the attributes of the transformation of protest socio-political movements and organizations in the

28 Кольцов В. Методологічний інструментарій дослідження демократичного транзиту. Актуальні проблеми філософії та соиіології. 2016. № 10. С. 65-67.

${ }^{29}$ Horowitz S., Browne E. Sources of Post-Communist Party System Consolidation: Ideology Versus Institutions. Party Politics. 2005. Vol. 11. No. 6. P. 689-706. 
party in 1989-1993 or the duration and consequences of the different perspectives of political transit initiated by political elites in the sample of countries analyzed ${ }^{30}$. Moreover, it is also important that the leading role in the fact that protest/opposition movements and organizations successfully or unsuccessfully transformed into the party was primarily played by political elites and strategies that incorporated them into various determinative moments of political transit.

Another indicator of the causality of the protests transformation by the communist regime of socio-political movements and organizations into political parties, as well as the independent (separate) formation of political parties in post-communist Poland, Hungary, the Czech Republic and Slovakia (Czechoslovakia), was influenced by the peculiarities of historical development and particularity, reflection in the determinations of the political process of the late 80 's - early 90's of the XX century. In this context, according to the opinion of A. Gzymalo-Buss, the processes of transformation of communist parties of «real socialism» regimes into other political forces in the conditions of formation and consolidation of democracy were important and additional to the formation of political opposition. The fact is that in the act of transformation of the former communist parties of Poland, Hungary and Czechoslovakia some procedural refinements were concealed to the case analyzed in our context: if the decline and / or restoration of communist parties depended on the history of communist political forces until 1989, then it could not arising from the transformation of the protest / opposition groups of the communist regime also had to be explained by the historical attributes of the development of such groups (which is the focus of the previous section of the study). Therefore, it is advisable to check the extent to which the organizational legacy and genesis of protest socio-political movements and organizations influenced the ways and features of the formation, development and imitation of party competition in the future (especially in the early 1990s).

In this case, two research positions and strategies are important: 1) an examination of how likely protest / opposition movements were in Poland, Hungary and Czechoslovakia earlier than 1989; 2) checking the level of antagonism between the communist regime and protest / opposition movements until 1989. In view of this, we consider that the evaluation of the listed factors, positions and strategies is effective in explaining the factors that influenced the effectiveness or inefficiency of the processes of transformation of protest / opposition socio-political movements and

${ }^{30}$ Reich G. Coordinating Party Choice in Founding Elections: Why Timing Matters. Comparative Political Studies. 2001. Vol. 34. No. 10. P. 1237-1263. 
organizations into political parties in the countries that are now members of the Visegrad Group. Moreover, this marker is also important in assessing the institutionalization of party systems, which is an indirect manifestation of the institutionalization of political opposition (which will be discussed in detail in the following sections of the study).

In this context, it should be noted that there can only be two research positions. The first assumes that there is a «well-organized» and «strong» opposition or protest movement that is in antagonistic relations with the authoritarian communist regime, and this is quite sufficient reason and motivation for a consolidated position in the conditions of his (this movement) transformation into a strong political party during the postcommunist phase of the development of a certain polity. However, there are a number of comments on this, which, for example, boil down to the case that was peculiar to the communist and post-communist stages of Poland's development. The fact is that in this country, as noted above, there was a very powerful and popular solidarity-based anti-communist protest movement that failed to transform itself into a single strong political party. The second position, however, argues that this is not exceptional and not even surprising, because by organizational structure such (as in Poland) movement had to be transformed into a number of not necessarily strong parties with sufficiently powerful representative capabilities. This was due primarily to the breadth of interests that had been incorporated into the social base of "Solidarity». The reason for this is that the protest / opposition movement had deep roots in civil society, a large number of sympathizers and a tradition of mass membership ${ }^{31}$. And unlike and in justifying the second scientific position, parties that emerged from Hungarian anticommunist protest, as noted by D. Stark, were labeled as having no deep connection with elements of civil society. Accordingly, the examination of the outlined cases shows that in fact they were united by the opposite: a) «Solidarity», which suffered a significant loss of membership after the collapse of the communist regime, completely «dissolved» into incoherent fragments that did not resemble that of the «Solidarity» movement that existed in 1989; b) organized, but much weaker, Hungarian political protest / opposition, which faced a much milder communist regime, «spawned» at least two significant «post-opposition» (analyzed) political parties; c) In the Czech Republic, for example, the relatively weak anti-communist opposition, which had virtually no capacity to grow organizationally and combinatively into a solid political structure under the brutal communist

\footnotetext{
${ }^{31}$ Grabowski T. The Party That Never Was: The Rise and Fall of the Solidarity Citizens' Committees in Poland. East European Politics and Societies. 1996. Vol. 10. No. 2. P. 214-254.
} 
regime in Czechoslovakia, was almost completely transformed into a group of «technocrats-reformers» in the post-communist period of $1989^{32}$. On the basis of such experience it is concluded that it is appropriate to combine different practical components and theoretical and methodological perspectives of transformation of protest / opposition socio-political movements and organizations into political parties, since it allows comparing the preconditions of political-legal status with political connection and its connection the process of democratization in the region. Moreover, it regulates that the process of transformation of protest sociopolitical movements and organizations in the party should be discussed in a multifactorial and cross-thematic manner, in the form of a case-stage and regional comparisons, etc. ${ }^{33}$.

Let's start with the analysis of individual cases, because they allow us to identify as political protest to the communist regimes in each of the analyzed countries, transforming into official political opposition, poured into the process of forming new political parties and even generating new party systems. And then let's look at the patterns of transformation processes cross-thematically and regionally, which will reveal additional analytical similarities and differences.

We start chronologically from the case of Poland, the only country in the region where protests of social and political movements, especially the «Solidarity» trade union movement, gained organizational significance and became mass organizations with a considerable opportunity to exert pressure on the communist regime by the end of the 1980s. (and in particular, in the case of «Solidarity», in 1980-1981.). However, in this case, the «fate» of «Solidarity» after the 1989 parliamentary elections is of particular interest. Exploring it, we proceed from the fact that, being a larger organization of social-democratic ideological orientation, it consisted of micro-groups united solely by the idea that Poland should be an independent democratic country. Accordingly, in the wake of the 1989 elections, it became a parliamentary faction, and internal organizational conflicts began to emerge and intensify in the «Solidarity» environment, causing the organization to lose electoral support $^{34}$. It lasted until December 1990, when the first national elections of

\footnotetext{
${ }^{32}$ Innes A. Czechoslovakia: The Short Goodbye. New Haven: Yale University Press, 2001. $334 \mathrm{p}$.

${ }^{33}$ Кольцов В. Роль політичної опозиції у краху режимів «реального соціалізму» в сучасних країнах Вишеградської групи (70-80 роки XX ст.). Вісник національного технічного університету Украйни «Київський політехнічний інститут». Серія: Політологія. Соиіологія. Право. 2016. № 3-4 (31-32). С. 154-157.

${ }^{34}$ Cockerham W. Health and Social Change in Russia and Eastern Europe. Routledge, 1999. P. 157.
} 
the President of Poland took place, the victory of which was won by Lech Wałęsa. As a result, in February 1991, M. Krzaklewski was elected leader of «Solidarity». It is because of this vision of the future post-protest / post-opposition movement on the part of Lech Wałęsa and the new leadership of the organization that diverged, on the basis of which Solidarity began to position itself as a political force of parliament, increasingly critical of the government.

As a result, in order to participate in the 1991 parliamentary elections, it was decided to transform «Solidarity» into a party of the same name ${ }^{35}$. But as a result of elections determined by a large number of competing political forces, many of which appealed to the legacy of post-communism, «Solidarity» (S) received only $5.1 \%$ of the vote (or 27 seats in the Seim) ${ }^{36}$. In 1992, the party attempted to confront a government created by democratic parties: first, a one-hour and later a two-hour strike against the government cabinet. And in May 1993, "Solidarity» MPs proposed to declare a noconfidence vote and promoted the resignation of the coalition government by Kh. Sukhotska, which in turn ended with the announcement of early parliamentary elections. But according to their results, «Solidarity» did not get seats in the Seim (winning $4.9 \%$ of the vote at the five percent barrier) ${ }^{37}$. The paradox is that, with no other option, «Solidarity» began to cooperate with its former adversary, the Polish Trade Union Alliance (OPZZ). However, in the 1995 presidential election, «Solidarity» supported Lech Wałęsa candidacy.

This is the sole story of the "Solidarity» Party. However, in 1996, more than 30 Liberal, Conservative and Christian-Democratic forces formed the «Electoral Action of Solidarity» (AWS), a political party in the form of an electoral coalition. In 1997, the party was renamed the «Solidarity of Right Electoral Action» (AWSP). In 1997-2001, the political force was the largest in parliament and twice participated in the formation of government offices (led by E. Buzek). But because of the failures of Poland's development, corruption problems, internal contradictions in the electoral coalition, as well as the failure of the last one in the 2001 parliamentary elections, the «Solidarity»-based party received no mandate (winning $5.6 \%$ voters' votes, which was not enough formally to win the electoral coalition mandate). After that, the party departed from the political process, and subsequently its

${ }^{35}$ Kubicek P. Unbroken Ties: The State, Interest Associations, and Corporatism in PostSoviet Ukraine. Michigan: University of Michigan Press, 2000. P. 188.

${ }^{36}$ Nohlen D., Stöver P. Elections in Europe: A data handbook. Baden-Baden: Nomos Verlagsgesellschaft Mbh \& C., 2010. P. 1491.

${ }^{37}$ Ibid. 
dissolution. As a result, only one organization, called «Solidarity», continued to operate in Poland, a trade union that originates directly from the anti-communist socio-political movement and the trade union.

Another vector of the development of the anti-communist organization «Solidarity» and its transformation into political parties in the late 1980s and early 1990s was the focus and concentration of sympathizers and members of the socio-political movement around, above all, such individuals as Lech Wałęsa and B. Geremek. Back in 1988, they formed the basis for the formation of the semi-legal (up to 1989) Civic Committee «Solidarity» (or Civic Election Committee), which was represented in the Seim by the results of the "partially free» constituent parliamentary elections of 1989. In June 1989, the Parliamentary Civic Party (OKP) was formed on its basis. But due to the controversy, two structures were isolated from the parliamentary faction: 1) the conservative populist wing, on the basis of which the Party «Center`s Consent» (PC) emerged, led by L. Kaczynski; 2) the liberalintellectual wing that formed the «Civic Movement for Democratic Action» $(\mathrm{ROAD})$, which after some time joined three distinct parties - the «Democratic Union» (UD), the «Freedom Union» (UW) and the «Democratic Party» (PD). The most obvious division within «Solidarity» was during the 1990 presidential election campaign: the conservatives supported Lech Wałęsa and the liberals T. Mazowiecki. It is interesting that such division, although partly conditional, continues still to exist in Polish party politics. Thus, the transformation of «Solidarity» into a party in Poland did not significantly affect the generation of the current state of the party system, although it facilitated the competition and institutionalization of political opposition at the beginning of democratization processes.

In Hungary, political protest groups were not endowed with the same considerable organizational unity / depth as in Poland, but managed to form themselves in the late 1980s. Despite the fact that dissidence and other protests in Hungary, in particular in the 70's - early 80's of the twentieth century were virtually invisible, the deepening economic crisis in the mid to late 80 's of the twentieth century and the weakening of the communist regime as it sought ways out of the crisis, generated considerable space for opposition activity ${ }^{38}$. As a consequence, in the late 80 's of the twentieth century the selected groups of independent intellectuals began to form organizations with specific requirements and alternative political and economic proposals for reform.

38 Jenkins R. Stabilizing the Democratic Transition: The 1990 Hungarian Parliamentary Elections. Rutgers. URL: http://hi.rutgers.edu/szelenyi60/jenkins.html. 
The first of these is the Hungarian Democratic Forum (MDF), which appeared in 1987 on the basis of the tacit consent of supporters of the communist regime's reforms. The MDF grouped different writers and intellectuals from the national populist movement, who focused on the need for national and moral renewal, as well as on the rights and status of ethnic Hungarian minorities in neighboring countries. Soon this organization was transformed into a political party of the same name, which ideologically positioned itself as a center-right liberal-conservative and Christiandemocratic movement ${ }^{39}$. The party from 1990 to 2010 was represented in the national parliament of Hungary. At the same time, the party's electoral successes were steadily diminishing: from the status of the primary in the coalition offices of J. Antal and P. Borosh (1990-1994) to the status of the additional one in the coalition government of V. Orban (1998-2002) (in other cases, the party positioned solely as opposition ${ }^{40}$. As a result of the 2010 parliamentary elections, the party did not receive representation in the Legislature (2.2\% of the vote) and subsequently turned into another electorally unpopular party - the «Democratic Community of Welfare and Freedom» (JESZ) - finally ceasing to operate in 2011.

Another post-protest/post-dissident organization that emerged in Hungary in 1988 is the «Union of Free Democrats» (SzDSz). This opposition structure was formed on the basis of the so-called «Democratic Opposition Movement» in Budapest (from which, in 1988, the «Network of Free Initiatives» was formed.). But soon, including the 1990 parliamentary elections, the group transformed into a liberal political party of the same name, the «Union of Free Democrats» ${ }^{41}$. What is interesting is that during 1990-2010 the party received support mainly from the population of Budapest. During the opposition to the communist political regime, the political party radically advocated a change in the political, economic and social system of the country. Unlike the «Hungarian Democratic Forum», the analyzed post-protest party was a long-running electoral and coalition ally of the post-communist «Hungarian Socialist Party» (MSZP). Accordingly, the «Union of Free Democrats» in 1994-1998 and 2002-2008 (unlike 1990-1994, when it had the status of the largest opposition party) positioned itself as the coalition partner of the «Hungarian Socialist Party».

39 Enyedi Z. The Survival of the Fittest: Party System Concentration in Hungary. Jungerstam-Mulders S. Post-communist EU Member States: Parties and Party Systems. Burlington: Ashgate, 2006. P. 177-202.

${ }^{40}$ Ramet S. Central and Southeast European Politics Since 1989. Cambridge University Press, 2010. P. 80.

${ }^{41}$ Hlousek V., Kopecek L. Origin, Ideology and Transformation of Political Parties: EastCentral and Western Europe Compared, Ashgate, 2010. P. 115. 
But after that there was a split in the relations between the parties. On average, in 1990-2010, electoral support for this post-protest party was steadily diminishing. As a result of the 2010 parliamentary elections, the party did not receive representation in the Legislature, and in 2013 it was dissolved altogether.

The third Hungarian post-protest organization, which also emerged in 1988, is Fidesz. In its origin, it relied on a democratic youth movement created by graduates of I. Bibo Law College. Ideologically during this period, it was a shift from the center-right to the right spectrum of the National Conservative Party ${ }^{42}$. Moreover, at the time of formation, given the position of the youth movement, it was necessary to speak about the libertarian anti-communist orientation of the party. This, according to P. Kende, was manifested in the fact that by 1993, the party's statute provided for the highest age limit of party members at the level of 35 years. However, since the mid 90's of the twentieth century (after the failure of the 1994 parliamentary elections) the party began to change its ideological orientation. Since then, it has gradually begun to acquire the features/attributes of technocratism, Hungarian nationalism, social conservatism, «soft» euroscepticism, national populism. In 1995, due to modernization, the name of the political party was changed / modified Fidesz / Hungarian Civic Party (Fidesz-MPSz). However, another interesting thing is that, being overwhelmingly opposition in the Hungarian Legislature, thereafter began a steady increase in the electoral success of the party (from $7.02 \%$ of the vote in 1994 to $52.73 \%$ of the vote in 2010 and $44.87 \%$ of the vote) voters in 2014.). As a consequence, in 1998-2002 and since 2010, the party has positioned itself as a government (V. Orbán's cabinets) and even dominant in the party system of Hungary (though in coalition with the Christian Democratic People's Party, KDNP).

Thus, in Hungary, three key protest groups prior to the roundtable negotiations in 1989 were able to develop their own programs and organizational structure in the form of political parties. As a result, the negotiations with the communist regime were characterized by internal and opposition power. It was on the basis of this specificity, in particular the influence of protest groups and parties, that in 1989 it was decided to hold a referendum, and in 1990 - the constituent parliamentary elections. In addition, on this basis, unlike Poland, the formation of post-protest parties took place in Hungary and, accordingly, the generation of organizational

${ }^{42}$ Szabo M. From a Suppressed Anti-Communist Dissident Movement to a Governing Party: The Transformations of Fidesz in Hungary. Corvinus Journal Of Sociology And Social Policy. 2011. Vol. 2. No. 2. P. 46-47. 
experience, which in the future had a positive impact on the functioning of parties and the party system of the country.

In the Czech Republic and Slovakia (initially within the Czechoslovakia), protest / opposition groups had significantly fewer opportunities to organize effectively themselves in political parties and movements. Although in the late 80's of the twentieth century, there was an increase in protest groups in the country ${ }^{43}$, they were usually positioned as poorly structured and insignificant in size (public support). In addition (given the strength of the communist regime discussed in the previous section of the study), such opposition / protest organizations have been severely repressed by the authoritarian regime.

This was evident in the case of the Czech part of Czechoslovakia that the formation of the Civic Forum (OF) - the main protest / opposition movement within the historical Czech Republic, which initiated the roundtable negotiations in Czechoslovakia and the collapse of the communist regime in this federation, could not have taken place until November 1989, when there was a brutal repressive suppression of the student demonstration in Prague, which led to the «velvet revolution». In this context, the specificity of the formation of the anti-communist protest / opposition movement in the Czech Republic was that the Civic Forum did not have the time and organizational capacity to develop itself (even in comparison with Hungary) just before the roundtable negotiations and to the point where he took political control of the country. This was due to the fact that in June 1990, when the first democratic (constituent) elections took place in the Czech Republic and Czechoslovakia, an organization that did not have a consolidated program of further development, but spoke exclusively about overcoming the communist regime, even though it received support of almost 50\% of Czech voters and more than $36 \%$ of Czechoslovakia's voters overall (with the KSCS succeeding in $13 \%$ of voters' support), but not positioned as a political party. And this is at a time when other political parties have already been formed or restored in the Czech Republic - the Movement for Autonomous Democracy - the Moravian and Silesian Party (HSD-SMS), the Christian and Democratic Union (KDU), etc. Moreover, the organizational non-solidarity of the movement emerged immediately after the 1990 voters, when a political confrontation broke out between V. Havel (leader of the Civic Forum, who was elected President of Czechoslovakia in 1989) and the formal leadership of the protest / opposition Civic Forum the person of J. Urban, and soon in

${ }^{43}$ Tůma O. Czechoslovakia. Pollack D., Wielgohs J. Dissent and opposition in communist Eastern Europe: origins of civil society and democratic transition. Ashgate, 2004. P. 38-40. 
the person of V. Klaus). As a result, protest / opposition unity became questionable and at the January 1991 congress of the Civic Forum, supporters of V. Klaus declared the need to form a new political force - the Civic Democratic Party (ODS). Throughout the post-communist history of the Czech Republic, to a lesser extent today, it is the largest conservative (liberal-conservative) and partly Eurosceptic center-right party of the Czech Republic (formally created in April 1991), modeled after the British Conservative Party ${ }^{44}$, but has in its structure political groups / factions of different ideological lines - social-conservative, national-conservative, neoconservative and national-liberal. At the same time, it is noteworthy that at the time of its formation, the Civic Democratic Party was positioned as a «pro-market» (liberal) political force, and in its development was characterized as a stable party, on the basis of which the Czech Republic's party system was institutionalized. This is manifested in the fact that the party is a permanent member of the Czech Parliament and periodically forms governmental (mostly coalition) cabinets. In 1992-1998, it was positioned as the largest parliamentary party and the dominant government party (the three coalition cabinets of V. Klaus and the coalition cabinet of J. Toshovsky). In 1998-2006, it was the largest opposition party in the Czech Republic (as opposed to the Czech Social Democratic Party, CSSD, dominant during this period). During 2006-2013 (except for the period 2009-2010), the party repositioned itself as the largest government (with 2006-2009 being the dominant government and the largest in parliament). However, since 2013 the electoral ratings of the party have worsened and it has transformed into an opposition one.

At the same time, another party in the Czech Republic emerged from the remnants of the Civic Forum in 1991 - the centrist liberal, social liberal, national liberal, and environmentalist $(\mathrm{OH})$ movement, which even in 19911992 even had representation at the level of several federal ministers. Thus, the protest / opposition movement organized in the short term in the Czech Republic successfully transformed itself into a party, first of all, into the ODS, which immediately became the basis for the institutionalization of this country's party system.

In the rest of the federal republic, and later in the independent state Slovakia - the development of the protest / opposition movement was similar.

At the same time, a centrist Liberal Democratic Party (ODU) was formed on the other part of the post-protest / post-opposition movement

${ }^{44}$ Hanley S. The New Right in the New Europe: Czech transformation and right-wing politics, 1989-2006. London: Routledge, 2008. P. 9. 
«Community against Violence», but a little earlier, including 1989, but it only existed until November 1992. According to analogy with the Czech Republic, only one post-opposition political party has succeeded in Slovakia, but it is still not represented in the national parliament today. Against this background, it is quite clear that protest / opposition movements were determinant in the formation and early stages of the party system in Slovakia.

\section{CONCLUSIONS}

Summarizing the attributes and logic of the formation and political influence of protest / opposition movements on the formation of parties and party systems in the modern countries of the Visegrad Group in 1989-2017, we can draw the following conclusions: a) the most politically (in particular by the result of constituent parliamentary elections) successful protest / opposition socio-political movements and organizations were in the Czech Republic and Hungary, and to a lesser extent in Poland and Slovakia; b) the largest number of socio-political movements, even those transformed into political parties that were represented in the national legislature, were in Hungary; c) the largest number of parties formed on the basis of protest / opposition movements was in Poland, slightly fewer in Hungary and the smallest in the Czech Republic and Slovakia; d) the most politically successful were political parties formed on the basis of protest / opposition movements in Hungary, less successful in Slovakia and the Czech Republic, and the least successful in Poland; e) parties that emerged from protest / opposition movements in the modern countries of the Visegrad Group were the most politically successful after the first (constituent) parliamentary elections, as well as in the first decade (90-ies of the XX century) after the collapse of the «real socialism» regimes. «And soon (except for the most part Hungary and to a lesser extent began to decline politically and even ceased to exist in some places; f) political parties formed on the basis of protest / opposition anticommunist socio-political movements are today (as of 2017) averagely marginalized or discontinued in Poland and Slovakia, much weaker than before in the Czech Republic, and very influential as before in Hungary; g) political parties formed on the basis of protest / opposition movements had the greatest influence on the formation and institutionalization of party systems in Hungary and the Czech Republic, as well as in their time (especially in the 1990s) in Slovakia, and to a lesser extent - in Poland; h) political parties that emerged on the basis of protest anticommunist socio-political movements did not become the exclusive descriptors and attributes of the party systems of the Visegrad Group 
countries, given that the political and legal status of political opposition in the region is determined by a number of other attributes.

Based on the use of multifactorial and cross-thematic regional comparisons, it is also clear that parties emerging from anti-communist political protest / opposition in the modern countries of the Visegrad Group were largely rooted in the late 1980s.

As for evaluating the transformational logic and prospects of turning protest / opposition socio-political movements into political parties, in particular on the basis of an analysis of the roles and motivations of key actors in the environment of anti-communist protest / opposition, it is clear that these were important people, in particular, in the sense that they played a prominent leadership role in social and political movements until at least 1989, and participated in negotiations with the communist regime on the prospects and features of creating democratic systems.

Therefore, in most countries, it is the protest / opposition anti-communist socio-political movements that transform into political parties (even regardless of how politically successful they are afterwards), that is, the phenomena and processes of socio-political protest and, in particular, opposition, proved to be the initials in the newest period of party building.

\section{SUMMARY}

The article deals with the phenomenon of protest socio-political movements and organizations and their transformation in the late 1980s on the example of the modern countries of the Visegrad Group. It has been determined that protest socio-political movements have been largely constructed on the logic and strategies of opposition resistance. It turned out that, relying primarily on the «forces» of society, for the first time in the conditions of «real socialism» regimes, they began to put pressure on political power and the party-state over how they functioned and were supposed to function. It was found that the three key factors that configured variations were first the changes and subsequently the collapse of the «real socialism» regimes in the modern countries of the Visegrad Group were: mobilization of the population at large and civil society in particular; the ability of protest / opposition groups to act; the level of cohesion of the communist leadership and the quality of its response to the crisis of the system. Based on the use of multifactorial and cross-thematic regional comparisons, it is also averagely evident that parties that emerged from anticommunist political protest / opposition in the modern countries of the Visegrad Group were largely rooted in the late 1980s. It has been proved that the most politically (particularly by the results of the constituent 
parliamentary elections) successful protest / opposition socio-political movements and organizations were in the Czech Republic and Hungary, and to a lesser extent in Poland and Slovakia, and the largest number of sociopolitical movements, even transformed in political parties that were represented in the national legislature were in Hungary.

\section{REFERENCES}

1. Ackerman P., Duvall J. A Force More Powerful. A Century of Nonviolent Conflict. New York: St. Martin's Press, 2000. 544 p.

2. Batt J. The End of Communist Rule in East-Central Europe. Government and Opposition. 1991. Vol. 26. No. 3. P. 368-390.

3. Bernhard M. Civil Society and Democratic Transition in East Central Europe. Political Science Quarterly. 1993. Vol. 108. No. 2. P. 307-326.

4. Bozöki A. Post-Communist Transition: Political Tendencies in Hungary. East European Politics and Societies. 1990. Vol. 4. P. 211-230.

5. Bruszt L. 1989: the Negotiated Revolution in Hungary. Social Research. 1990. Vol. 57. No. 2. P. 365-387.

6. Bruszt L., Stark D. Remaking the Political Field in Hungary: From the Politics of Confrontation to the Politics of Competition. Banac I. Eastern Europe in Revolution. Ithaca: Cornell University Press, 1992. P. 13-71.

7. Bugajski J., Pollack M. East European Fault Lines. Dissent, Opposition and Social Activism. Boulder, San Francisco, London: Westview Press, $1989.333 \mathrm{p}$.

8. Cockerham W. Health and Social Change in Russia and Eastern Europe. Routledge, 1999. 284 p.

9. Curp T. The politics of ethnic cleansing: The P.P.R., P.Z.Z., Wielkopolska nationalist revolution, 1944-1946. Nationalities Papers. 2001. Vol. 29. No. 4. P. 575-604.

10. Duverger M. Political Parties: Their organization and activity in the modern state. London: Methuen, 1954. 439 p.

11. Ekiert G. Democratization Processes in East Central Europe: A Theoretical Reconsideration. British Journal of Political Science. 1991. Vol. 21. P. 285-313.

12. Ekiert G., Kubik K. Contentious politics in new democracies: East Germany, Hungary, Poland, and Slovakia, 1989-1993. World Politics. 1998. Vol. 50. No. 4. P. 547-582.

13. Enyedi Z. The Survival of the Fittest: Party System Concentration in Hungary. Jungerstam-Mulders S. Post-communist EU Member States: Parties and Party Systems. Burlington: Ashgate, 2006. P. 177-202.

14. Ettrich F. Die «Zerstörung des Zerstörten» (Hegel). Der Zusammenbruch des Sozialismus sowjetischen Typs als 
sozialwissenschaftliches Problem. Brussig M., Ettrich F., Kollmorgen R. Konflikt und Konsens: Transformationsprozesse in Ostdeutschland. Leske, Budrich, Opladen, 2003. P. 215-254.

15. Gati C. Reforming Communist Systems: Lessons from the Hungarian Experience. Griffith W. Central and Eastern Europe, The Opening Curtain. Boulder, CO: Westview Press, 1989. P. 235-236.

16. Grabowski T. The Party That Never Was: The Rise and Fall of the Solidarity Citizens' Committees in Poland. East European Politics and Societies. 1996. Vol. 10. No. 2. P. 214-254.

17. Grzymala-Busse A. Redeeming the Communist Past: The Regeneration of Communist Parties in East-Central Europe. Cambridge: Cambridge University Press, 2002. 341 p.

18. Hankiss E. In Search of a Paradigm. Daedalus. 1990. Vol. 119. No. 1. P. 183-214.

19. Hanley S. The New Right in the New Europe: Czech transformation and right-wing politics, 1989-2006. London: Routledge, 2008. $292 \mathrm{p}$.

20. Hlousek V., Kopecek L. Origin, Ideology and Transformation of Political Parties: East-Central and Western Europe Compared, Ashgate, 2010. $263 \mathrm{p}$.

21. Horowitz S., Browne E. Sources of Post-Communist Party System Consolidation: Ideology Versus Institutions. Party Politics. 2005. Vol. 11. No. 6. P. 689-706.

22. Innes A. Czechoslovakia: The Short Goodbye. New Haven: Yale University Press, 2001. 334 p.

23. Jenkins R. Movements Into Parties: The Historical Transformation of the Hungarian Opposition. Program on Central and Eastern Europe Working Paper Series. 1992. No. 25. 80 p.

24. Jenkins R. Stabilizing the Democratic Transition: The 1990 Hungarian Parliamentary Elections. Rutgers. URL: http://hi.rutgers.edu/szelenyi60/jenkins.html.

25. Kende P., Smolar A. Die Rolle oppositioneller Gruppen am Vorabend der Demokratisierung in Polen und Ungarn (1987-1989). Köln, 1989. S. 64-93.

26. Kenney P. A Carnival of Revolution: Central Europe 1989. New Jersey: Princeton University Press, 2002. 341 p.

27. Kolakowski L. Hope and Hopelessness. Survey. 1971. Vol. 17. P. 42-48.

28. Kubicek P. Unbroken Ties: The State, Interest Associations, and Corporatism in Post-Soviet Ukraine. Michigan: University of Michigan Press, 2000. 275 p. 
29. Michnik A. The New Evolutionism. Survey. 1976. Vol. 22. P. 272-274.

30. Nohlen D., Stöver P. Elections in Europe: A data handbook. Baden-Baden: Nomos Verlagsgesellschaft Mbh \& C., 2010. 2070 p.

31. Pollack D. Politischer Protest. Politisch alternative Gruppen in der DDR. Opladen: Leske und Budrich, 2000. $282 \mathrm{s.}$

32. Prizel I. National Identity and Foreign Policy. Nationalism and Leadership in Poland, Russia, and Ukraine. Cambridge University Press, 1998. 443 p.

33. Rakovski M. Towards an East European Marxism. New York: St. Martin's, 1978. 139 p.

34. Ramet S. Central and Southeast European Politics Since 1989. Cambridge University Press, 2010. 600 p.

35. Reich G. Coordinating Party Choice in Founding Elections: Why Timing Matters. Comparative Political Studies. 2001. Vol. 34. No. 10. P. 1237-1263.

36. Siedlecki M. Time for Positive Action. East European Reporter. 1989. Vol. 3. No. 4.

37. Skilling G. Czechoslovakia Between East and West. Griffith W. Central and Eastern Europe, The Opening Curtain. Boulder, CO: Westview Press, 1989. $458 \mathrm{p}$.

38. Snyder T. The Polish-Lithuanian commonwealth since 1989: national narratives in relations among Poles, Lithuanians, Belarusians and Ukrainians. Nationalism and Ethnic Politics. 1998. Vol. 4. No. 3. P. 1-32.

39. Sonntag S. Poland. Pollack D., Wielgohs J. Dissent and opposition in communist Eastern Europe: origins of civil society and democratic transition. Ashgate, 2004. P. 3-28.

40. Stark D., Bruszt L. Postsocialist pathways: Transforming politics and property in East-Central Europe. Cambridge: Cambridge University Press, 1998. 284 p.

41. Szabo M. From a Suppressed Anti-Communist Dissident Movement to a Governing Party: The Transformations of Fidesz in Hungary. Corvinus Journal Of Sociology And Social Policy. 2011. Vol. 2. No. 2. P. 47-66.

42. Szabo M. Repertoires of Contention in Post-Communist Protest Cultures. Social Research. 1996. Vol. 63. P. 1155-1182.

43. Szabo M. Some Lessons of Collective Protests in Central European Post-Communist Countries: Poland, Hungary, Slovakia, and East Germany Between 1989-1993. East Central Europe. 2000. Vol. 27. No. 1. P. 59-75.

44. Tilly C. From Mobilization to Revolution. Addison-Wesley, 1978. 349 p. 
45. Tůma O. Czechoslovakia. Pollack D., Wielgohs J. Dissent and opposition in communist Eastern Europe: origins of civil society and democratic transition. Ashgate, 2004. P. 29-50.

46. Urban L. Hungary in Transition: The Emergence of Opposition Parties. Telos. 1989. Vol. 79. P. 108-118.

47. Wolchik S. Czechoslovakia's «Velvet Revolution». Current History. 1990. Vol. 89. No. 551. P. 413-437.

48. Кольцов В. Вплив протестних суспільно-політичних рухів і організацій на формування політичної опозиції в сучасних країнах Вишеградської групи (70-80 роки XX століття). Молодий вчений: науковий журнал. 2017. № 6 (46). С. 28-32.

49. Кольцов В. Методологічний інструментарій дослідження демократичного транзиту. Актуальні проблеми філософії та соиіологіï. 2016. № 10. С. 65-67.

50. Кольцов В. Роль політичної опозиції у краху режимів «реального соціалізму» в сучасних країнах Вишеградської групи (7080 роки ХХ ст.). Вісник національного технічного університету Украӥни «Київський політехнічний інститут». Серія: Політологія. Соиіологія. Право. 2016. № 3-4 (31-32). С. 154-157.

\section{Information about the author: Koltsov V. M.,}

$\mathrm{PhD}$ in Political Sciences, Associate Professor at the Department of Political Theories of the National University «Odessa Law Academy» 2, Academichna str., Odesa, 65009, Ukriane 